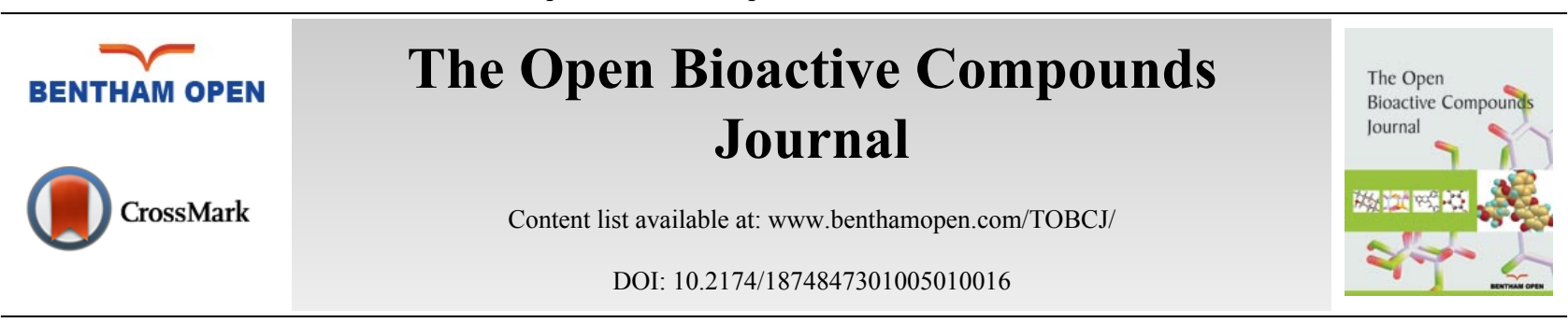

RESEARCH ARTICLE

\title{
Chemical Composition and Biological Activity of the Essential Oil and Solvent Extracts of Scaligeria Nodosa
}

\author{
Amir Reza Jassbi ${ }^{*}$, Mehdi Zare and Fatemeh Heidary Jamebozorgi \\ Medicinal and Natural Products Chemistry Research Center, Shiraz University of Medical Sciences, Shiraz, Iran
}

Received: May 23, 2017

Revised: August 23, 2017

Accepted: August 24, 2017

\begin{abstract}
:
Background:

The essential oil and three solvent extracts of the aerial parts of Scaligeria nodosa (Boiss.) that were collected in Bamu Mountains (Iran), were screened for their antioxidant, antimicrobial properties and total phenolic contents for the first time.
\end{abstract}

\section{Methods:}

The essential oil was extracted by hydrodistillation and analyzed by capillary gas chromatography-mass spectrometry (GC-MS) and GC flame ionization detector (GC-FID).

\section{Results:}

Forty five components were identified in the oil, among them, germacrene D (18.1 $\pm 0.1 \%)$, bicyclogermacrene $(1.4 \pm 0.0 \%)$, and spathunelnol $(2.7 \pm 0.0 \%)$ were the major sesquiterpenoids, $n$-tetradecanol $(4.9 \pm 0.0 \%)$ was the most abundant fatty alcohol and diisobuthyl phthalate $(43.9 \pm 0.2 \%)$ was the most abundant constituent. The extracts of aerial parts of $S c$. nodosa were prepared using different solvents; dichloromethane (DCM), methanol (MeOH) and $\mathrm{MeOH}: \mathrm{H}_{2} \mathrm{O}$ (80:20). Antibacterial activity of the oil and each solvent extract was tested against three Gram-positive and three Gram-negative bacteria by nutrient broth micro dilution method. Among the tested microorganisms, Staphylococcus epidermidis $\left(\mathrm{IC}_{50} 1.25-5 \mathrm{mg} / \mathrm{ml}\right)$, Bacillus subtilis $\left(\mathrm{IC}_{50} 1.25 \mathrm{mg} / \mathrm{ml}\right)$ and Escherichia coli $\left(\mathrm{IC}_{50} 1.25 \mathrm{mg} / \mathrm{ml}\right)$ were the most susceptible to the applied oils and the extracts. The antioxidant potential and total phenol contents of the extracts were assessed by 2,2-diphenyl-1-picrylhydrazyl (DPPH) radical scavenging assay and FolinCiocalteu reagent, respectively. Methanol and $80 \%$ methanol extracts of the plant showed relatively weak DPPH radical scavenging activity and low amounts of total phenol contents.

Keywords: Scaligeria nodosa, Apiaceae, Essential oil, Antibacterial, Antioxidant, Gas chromatography.

\section{INTRODUCTION}

The Apiaceae Lindl. or Umbelliferae is a family of usually aromatic plants with hollow stems commonly known as umbellifers. The family Apiaceae comprises 300 - 455 genera with 3000 - 3750 species distributed in the northern hemisphere $[1,2]$. In the Iranian flora, at least 112 genera including 316 species with about 75 endemic plant species are introduced for the family Apiaceae [3]. The aromatic smell of most species is due to the presence of oleoresin or essential oils in their different organs [4]. Seven Scaligeria species are reported in Iran, of which two: Sc. elata and Sc. nodosa are endemic [5]. Sc. nodosa is distributed in the Fars, Hamadan, Esfahan, Markazi and Lorestan Provinces of Iran $[5,6]$. Chemical constituents of the essential oil of Sc. assyriaca from Khorasan Province of Iran, were studied by GC-MS and the main components in its leaves and fruits were reported as germacrene D and myristicin, respectively [7]. The chemical compositions of the essential oils (EOs) from different parts of Sc. tripartita were analyzed. Geijerene

\footnotetext{
* Address correspondence to this author at Medicinal and Natural Products Chemistry Research Center, Shahid Abaeiyan Ave., Zip: 71348-53734, Shiraz, Iran, Tel: +98-071-32303872, Fax:+98-071-32332225; E-mails: jassbiar@sums.ac.ir; arjassbi@hotmail.com
} 
was detected as one of the major constituents in the stems, leaves (37\%) and fruits (55\%), while epoxy pseudoisoeugenol angelate (37\%) was reported as the main compound in the roots oil [8]. Nine components were detected in the EO of Sc. lazica, among which (Z)- $\beta$-farnesene was the major constituent [9, 10$]$. Germacrene D $(67.9 \%)$ was reported as the major constituent of the EO of the aerial parts of Sc. falcarioides among 24 compounds [11].

To the best of our knowledge there is no phytochemical or biological activity report on Sc. nodosa; therefore, the main aim of this research was to characterize the chemical composition of the EO and the antibacterial activity, total phenol contents and antioxidant activity of the oil and different solvent extracts.

\section{MATERIAL AND METHOD}

\subsection{Plant Samples Collection}

Scaligeria nodosa Boiss. was collected in spring 2012 from Bamu Mountain in the North of Shiraz (2941'46.36” N and 52 41'58.16" E). The plant identification was confirmed by Dr. M. Khosravi at the Department of Biology, University of Shiraz, Iran and a voucher specimen (no. PC-91-1-6.1) was deposited at the herbarium of the Medicinal and Natural Products Chemistry Research Center, Shiraz, Iran. Aerial parts of the plant were air-dried at room temperature $\left(25^{\circ} \mathrm{C}\right)$ in the shade.

\subsection{Extraction of Essential Oil}

The essential oil $(0.1 \% \mathrm{v} / \mathrm{w})$ from $100 \mathrm{~g}$ of plant material was extracted for $5 \mathrm{~h}$, using a British Pharmacopeia (BP) hydrodistillation apparatus. The yellowish oil was dried over anhydrous sodium sulfate and stored in a tightly closed dark vial and kept at $4^{\circ} \mathrm{C}$ until used in the antibacterial tests and GC-MS analyses.

\subsection{Solvent Extraction of the Plant}

The aerial parts of the plant were extracted by dichloromethane (DCM), methanol (MeOH) and $80 \% \mathrm{MeOH}$ solvents. Extracts were prepared as follows: $30 \mathrm{~g}$ of the dry plant after grinding was macerated in $300 \mathrm{~mL}$ of the solvents for $48 \mathrm{~h}$. The extraction was repeated twice and the resulting extracts were combined. The extract was then filtered and concentrated in a rotary evaporator under reduced pressure for the removal of the solvents to obtain residues of DCM $(0.350 \mathrm{~g} ; 1.66 \%)$, MeOH (1.240 g 4.13\%) and 80\% MeOH (1.165 g; 3.88\% w/w) extracts. The resulting concentrated extracts were kept at $-20^{\circ} \mathrm{C}$ until their use for antimicrobial and antioxidant and total phenol content tests [12].

\subsection{Gas Chromatography Analysis}

Gas chromatography was performed on an Agilent 6890N chromatograph (Agilent Technologies, USA), with a HP-5 capillary column $(30 \mathrm{~m} \times 0.25 \mathrm{~mm}: 0.25 \mu \mathrm{m}$ film thickness $)$. The oven temperature was programmed from $60^{\circ} \mathrm{C}$ to $240^{\circ} \mathrm{C}$ at $5^{\circ} \mathrm{C} / \mathrm{min}$ and kept $10 \mathrm{~min}$ at the final temperature. The carrier gas was $\mathrm{N}_{2}$ with a flow rate of $0.9 \mathrm{~mL} / \mathrm{min}$. Injector and detector (FID) temperature was kept at 240 and $250^{\circ} \mathrm{C}$, respectively. The injection volume was $0.4 \mu \mathrm{L}$ for the oils and -alkanes for calculation of the retention indices.

\subsection{Gas Chromatography-Mass Spectroscopy Analyses}

The GC-MS was carried out on an Agilent 7890N chromatograph, coupled to an Agilent 5975C mass spectrometer (Agilent Technologies, USA), operating at $70 \mathrm{eV}$ ionization energy, $0.5 \mathrm{~s} / \mathrm{scan}$ and the mass range: $35-400$, equipped with a HP-5MS capillary column (phenyl- (5\%) methyl-(95\%) siloxane, $30 \mathrm{~m} \times 0.25 \mathrm{~mm}$, film thickness $0.25 \mu \mathrm{m})$. Helium was used as the carrier gas at the constant flow of $0.9 \mathrm{ml} / \mathrm{min}$ and split ratio of 1:50. The oven temperature was $60^{\circ} \mathrm{C}$ rising to $250^{\circ} \mathrm{C}$ at a rate of $5^{\circ} \mathrm{C} / \mathrm{min}$, then held at $250^{\circ} \mathrm{C}$ for $10 \mathrm{~min}$; transfer line temperature was set at $250^{\circ} \mathrm{C}$.

\subsection{Antibacterial Activity}

\subsubsection{Microorganisms and Media}

The microorganisms consisted of three Gram-positive bacteria: Staphylococcus epidermidis (PTCC 1114), Bacillus subtilis (PTCC 1023), Staphylococcus aureus (PTCC1112), and three Gram-negative bacteria: Escherichia coli (PTCC1330), Klebsiella pneumoniae (PTCC1053) and Salmonella typhi (PTCC1609) which were obtained from the 
Persian Type Culture Collection (PTCC), Tehran, Iran.

\subsubsection{Minimum Inhibitory Concentration (MIC) Using Nutrient Broth Micro-Dilution (NBMD)}

Antimicrobial activity tests were performed by the nutrient broth micro-dilution method (NBMD). NBMD was performed by using serial dilution of a stock solution $(200 \mathrm{mg} / \mathrm{ml})$ of the essential oil and extracts of $S c$. nodosa in dimethyl sulfoxide (DMSO). The serial dilutions were performed by the addition of DMSO to reach a final concentration of $0.125-5 \mathrm{mg} / \mathrm{ml}$ of the above mentioned tests samples. An aliquot of the samples $(5 \mu \mathrm{L})$ was added to $95 \mu \mathrm{l}$ of fresh media followed by $100 \mu \mathrm{l}$ of the bacterial suspension ( $\mathrm{OD}=0.1$ at $600 \mathrm{~nm}$ ) in a 96-well plate. Chloramphenicol was used as a positive control. The plates were incubated at $37^{\circ} \mathrm{C}$ for $24 \mathrm{~h}$ in a shaking incubator. Antibacterial activity was detected using a colorimetric method by adding $10 \mu \mathrm{L}$ of $0.5 \%$ INT solution in water in each well at the end of the incubation period for further $30 \mathrm{~min}$. The MIC was defined as the lowest concentration of the test solution that inhibited the growth of the bacteria [13].

\subsection{Determination of the Free Radical Scavenging (Antioxidant) Activity}

The antioxidant activity of the plant extracts was measured by the method of Blois [14] with some modifications [15] and compared to that for quercetin as a natural standard radical scavenger. The extracts were diluted to different concentrations of $10 \mathrm{mg} / \mathrm{ml}, 5 \mathrm{mg} / \mathrm{ml}, 2.5 \mathrm{mg} / \mathrm{ml}, 1.25 \mathrm{mg} / \mathrm{ml}$ and $0.625 \mathrm{mg} / \mathrm{ml} .5 \mu$ aliquots of the extract dilutions were mixed with $195 \mu \mathrm{l}$ of the $100 \mu \mathrm{M}$ DPPH methanol solution. After 30 min shaking of the solutions in the dark, the absorptions of the DPPH solutions were measured at $517 \mathrm{~nm}$. Quercetin was used as a positive control. Inhibition ratio (percent) was calculated from the following equation: Percentage of DPPH reduction $\left.=\left(\left(A-A_{1}\right) / A\right) \times 100\right)$, where $A$ is the absorbance of the control, and $\mathrm{A}_{1}$ is the absorbance in the presence of sample.

The $\mathrm{IC}_{50} \mathrm{~s}$ were calculated by linear regression equations of the DPPH inhibition percentage obtained from different concentrations of the extracts and the standard antioxidants, using Microsoft Excel and Curve Expert statistical programs $[12,15]$.

\subsection{Determination of the Total Phenol Content}

The total phenol contents of the DCM, MeOH and $80 \% \mathrm{MeOH}$ extracts were determined by the Folin-Ciocalteu method as described previously [16]. Briefly, in each micro test well plate, $5 \mu \mathrm{l}$ of the $10 \mathrm{mg} / \mathrm{ml}$ plant extracts or the standard gallic acid solution, $158 \mu \mathrm{L}$ distilled water and $10 \mu \mathrm{l}$ Folin-Ciocalteu reagents was added and the solution was shaken briefly on a vortex mixer. After 8.5 min incubation at room temperature, $30 \mu \mathrm{L}$ of a $0.25 \%$ sodium carbonate solution was added to each well. The above solutions were kept in the dark at room temperature for $2 \mathrm{~h}$ and the absorbance of the solutions was measured at $765 \mathrm{~nm}$ against the blank. The concentrations of the total phenolics were measured against a series of gallic acid standard solutions and expressed as mg equivalent of gallic acid in $1 \mathrm{~g}$ dry plant material [16].

\subsection{Identification of Compounds}

GC-Relative retention indices (RRI) for all constituents were calculated according to Van den Dool method [17], using the retention times of $n$-alkanes (C9-C24) as standards and the essential oil's peaks of the GC chromatograms on a HP-5 column under the same chromatographic conditions. In addition to the GC-RRIs, the compounds were identified by comparison of their mass spectra with the authentic mass spectra [18]. For quantification purposes, relative area percentages obtained by GC-FID were used without the use of correction factors.

\section{RESULTS AND DISCUSSION}

Hydrodistillation of the aerial parts of Sc. nodosa resulted in a yellowish oil in $0.1 \%(\mathrm{w} / \mathrm{w})$ yield. Analysis of the EO was analyzed by GC-MS and GC-FID identified the main constituents as diisobuthyl phthalate $(43.9 \pm 0.2 \%)$, the sesquiterpenoids; germacrene D (18.1 $\pm 0.1 \%)$, bicyclogermacrene $(1.4 \pm 0.0 \%)$, and spathunelnol $(2.7 \pm 0.0 \%)$; and $n$ tetradecanol $(4.9 \pm 0.0 \%)$ as the most abundant fatty alcohol. The monoterpenoids $(1.4 \%)$ constituted a small fraction of the oil (Table 1).

The major constituent of the oil, diisobuthyl phthalate (DBP) and other phthalic acid esters have been reported in several terrestrial plants, microbial strains and marine algae and sponges [19]. The biosynthesis of these types of compounds that are also used as plasticizers and in pharmaceutical paints industries is a matter of several debates [20]. Recently, DBP is reported as a natural metabolite derived from the shikimate pathway and biosynthesized by three 
filamentous fungi strains: Penicillium lanosum, Trichoderma asperellum and Aspergillus niger. In addition to isolation from the above mentioned fungal extracts, the crude enzyme activity extracted from the fungi catalyzed the phthalate esters biosynthesis when glucose or protocatechuic acid and butanol were used as the substrates [21]. The phathalic acid esters also suggested as uptake by the living organism, plants, sponges, etc. from the environmental pollutions. We have quantified Bis (2-ethylhexyl) phthalate (dioctylphthalate; DOP) in different solvent extracts of Nepeta laxiflora collected from the same locality as we collected $S c$. nodosa and reported petroleum ether as the best extracting solvent. This may exclude the possibility of DOP originating from the solvent impurity [22]. The non-volatile DOP was determined in cow's milk and infant milk formula by HPLC [23]. DBP was detected in volatiles aroma of unprocessed rice [24]. The EOs of seven collections of Stachys inflata were reported to contain different amounts of DBP [25]. Didecyl-phthalate was isolated as a broad range antifungal agent from Burkholderia cepacia; an environmental bacterial strain. More than $95 \%$ of the essential oil of Leea indica, a perennial shrub, consisted of phthalic acids esters [26]. The oil has shown moderate antibacterial and antifungal activity [26]. To our knowledge, this is the first report on the composition of the essential oil from Sc. nodosa, while the main compounds in the oils of the leaves and fruits of Sc. assyriaca, collected from Khorasan province and the aerial parts of the plant Sc. assyriaca collected nearby $S c$. nodosa by us (unpublished data) were reported as undecane $(4.7,0.7,29.3 \%), \beta$-caryophyllene $(13.4,6.9,11.1 \%), \alpha$-copaene $(10.2,2.7,0 \%)$, germacrene D $(21.1,13.7,22.5 \%)$, kessan $(7.4,9.5,0 \%)$ and myristicin $(6.6,24.3,0 \%)$, respectively. The presence of sesquiterpenoids, but not monoterpenoids, long chain hydrocarbons or fatty alcohols, aldehyde or phenyl propanoids in different members of the Scaligeria species may be chemo taxonomically important but to prove the synthesis of DBP by the plants more experiments must be done [20,27].

Table 1. Chemical constituents (\%) of the essential oil of Sc. nodosa analyzed by GC-FID.

\begin{tabular}{|c|c|c|}
\hline Compound & RRI & $\operatorname{Area}(\%) \pm(\mathrm{SE})^{\mathrm{a}}$ \\
\hline$n$-heptanal & 902 & $0.11 \pm 0.0$ \\
\hline$\alpha$-pinene & 930 & $0.05 \pm 0.0$ \\
\hline$n$-heptanol & 929 & $0.2 \pm 0.0$ \\
\hline$\beta$-pinene & 974 & $0.5 \pm 0.0$ \\
\hline$\beta$-myrcene & 990 & $0.3 \pm 0.0$ \\
\hline$n$-octanal & 1003 & $0.11 \pm 0.0$ \\
\hline$p$-cymene & 1022 & $0.05 \pm 0.0$ \\
\hline limonene & 1025 & $0.1 \pm 0.0$ \\
\hline bornyl acetate & 1278 & $0.4 \pm 0.0$ \\
\hline thymol & 1290 & $0.2 \pm 0.0$ \\
\hline$\delta$-elemene & 1331 & $0.13 \pm 0.0$ \\
\hline$\alpha$-cubenene & 1344 & $0.17 \pm 0.0$ \\
\hline$\alpha$-copaene & 1368 & $0.9 \pm 0.0$ \\
\hline$\beta$-bourbonene & 1376 & $0.05 \pm 0.0$ \\
\hline$\beta$-cubebene & 1383 & $0.6 \pm 0.0$ \\
\hline$\beta$-elemene & 1388 & $0.21 \pm 0.0$ \\
\hline$\beta$-caryophyllene ${ }^{\mathrm{b}}$ & 1409 & $1.2 \pm 0.0$ \\
\hline$\beta$-copaene & 1427 & $0.24 \pm 0.0$ \\
\hline 6S-2,3,8,8-tetramethyltricyclo[5.2.2.0(1,6)]undec-2-ene & 1435 & $0.24 \pm 0.0$ \\
\hline$\alpha$-caryophyllene & 1441 & $0.4 \pm 0.0$ \\
\hline cis-muurola-4(14), 5-dine & 1451 & $0.9 \pm 0.0$ \\
\hline$\beta$-farnesen & 1459 & $1.2 \pm 0.0$ \\
\hline 2-dodecenal & 1469 & $0.2 \pm 0.0$ \\
\hline germacrene D & 1486 & $18.1 \pm 0.1$ \\
\hline Bicyclogermacrene & 1487 & $1.4 \pm 0.0$ \\
\hline$\alpha$-muurolene & 1490 & $0.5 \pm 0.0$ \\
\hline$\delta$-amorphene & 1499 & $0.18 \pm 0.0$ \\
\hline$\delta$-cadinene gamma & 1502 & $0.5 \pm 0.0$ \\
\hline$Z$ - $\gamma$-bisabolene & 1509 & $0.4 \pm 0.0$ \\
\hline$\delta$-cadinene & 1517 & $1.2 \pm 0.0$ \\
\hline trans-cadina-1(2),4-dine & 1524 & $0.2 \pm 0.0$ \\
\hline$\alpha$-cadinene & 1529 & $0.14 \pm 0.0$ \\
\hline
\end{tabular}


(Table 1) contd.....

\begin{tabular}{|c|c|c|}
\hline Compound & RRI & $\operatorname{Area}(\%) \pm(\mathrm{SE})^{\mathrm{a}}$ \\
\hline$\alpha$-calacorene & 1534 & $0.1 \pm 0.0$ \\
\hline spathunelnol & 1567 & $2.7 \pm 0.0$ \\
\hline caryophyllene oxide & 1570 & $1.1 \pm 0.0$ \\
\hline salvial-4-(14)-en-1-one & 1582 & $0.95 \pm 0.0$ \\
\hline$\beta$-atlantol & 1607 & $0.5 \pm 0.0$ \\
\hline 1,10-di-epi-cubenol & 1617 & $2.9 \pm 0.0$ \\
\hline$\alpha$-cardinol & 1632 & $0.45 \pm 0.0$ \\
\hline epi- $\alpha$-muurolol & 1639 & $0.4 \pm 0.0$ \\
\hline$\alpha$-cadinol & 1643 & $0.6 \pm 0.0$ \\
\hline 3-iso-thujopsanone & 1648 & $0.7 \pm 0.0$ \\
\hline$n$-tetradecanol & 1674 & $4.9 \pm 0.0$ \\
\hline Khusinol & 1681 & $0.7 \pm 0.0$ \\
\hline diisobutyl phthalate & 1670 & $43.9 \pm 0.2$ \\
\hline Total & & 90.88 \\
\hline
\end{tabular}

${ }^{a}$ The values are the means of three different FID area percentage \pm SE. ${ }^{\text {b }}$ The major compounds with more than $1.0 \%$ area concentration were formatted in bold font.

The EO showed antibacterial activity against gram positive bacteria B. subtilis and Staph. epidermidis $\left(\mathrm{IC}_{50}=1.25,5\right.$ $\mathrm{mg} / \mathrm{ml}$ ) and the gram negative E. coli $\left(\mathrm{IC}_{50}=1.25 \mathrm{mg} / \mathrm{ml}\right)$ (Table 2). The methanol extract was active against all of the assayed bacteria $\left(\mathrm{IC}_{50} \mathrm{~s}=1.25-5 \mathrm{mg} / \mathrm{ml}\right)$ except K. pneumonia (Table 2). B. subtilis, Staph. epidermidis, E. coli, P. aeruginosa and $K$. Pneumonia were all susceptible to the DCM extracts with $\mathrm{IC}_{50}=1.25 \mathrm{mg} / \mathrm{ml}$. Finally the weakest plant product was the $80 \%$ methanol extract, which only inhibited the growth of Staph. epidermidis at $\mathrm{IC}_{50}=2.5 \mathrm{mg} / \mathrm{ml}$, indicating a lesser role of possible phenolics or other polar compounds in the antibacterial activity of the plant material. The antioxidant activity and total phenol content of the plant's methanol and $80 \%$ methanol extracts were measured using DPPH radical scavenging activity and Folin-Ciocalteu reagents, but the DCM and EO were not active radical scavengers and did not contain detectable amounts of phenolics (Table 3). The above results indicate that Sc. nodosa may be more interesting for investigating antibacterial natural products rather than phenolic antioxidants and also suggest that DCM and $\mathrm{MeOH}$ extracts are the best plant extracts for antibacterial activity. The presence of DBP in the oil may be an indicator of natural or environmental polluting source, as they are reported harmful agents to human health.

Table 2. Antimicrobial potential (MIC ${ }^{\text {a }}$ of essential oil and solvent extracts from $S c$. nodosa, as determined by nutrient-broth micro-dilution bioassay.

\begin{tabular}{|c|c|c|c|c|c|c|c|}
\hline Plant Extract & Staph. aureus & Staph. epidermidis & B. subtilis & Sal. typhi & P. aeruginosa & E. coli & K. pneumoniae \\
\hline EO & NA & 5 & 1.25 & NA & NA & 1.25 & NA \\
\hline DCM & NA & 1.25 & 1.25 & 1.25 & NA & 1.25 & 1.25 \\
\hline $\mathrm{MeOH}$ & 5 & 5 & 1.25 & 5 & 5 & 1.25 & $N A$ \\
\hline $80 \% \mathrm{MeOH}$ & NA & 2.5 & NA & NA & NA & NA & NA \\
\hline Chloramphenicol & 0.0125 & 0.025 & 0.0125 & 0.05 & NA & 0.05 & 0.05 \\
\hline
\end{tabular}

a) Minimum inhibitory concentration (MIC) the plant extracts in the bacterial suspension in the nutrient broth media (mg/ ml) determined in three replicates. b) $\mathrm{NA}=$ not active

Table 3. Total phenolic content and DPPH radical scavenging potential of the methanol extracts from $S c$ nodosa.

\begin{tabular}{|c|c|c|}
\hline Plant Extract & IC50 DPPH $^{\mathbf{a}}$ & Total Phenol $^{\mathbf{b}}$ \\
\hline $\mathrm{MeOH}$ & $216.47 \pm 1.15^{\mathbf{c}}$ & $16.94 \pm 1.47$ \\
\hline $80 \% \mathrm{MeOH}$ & $195 \pm 3.8$ & $38.59 \pm 0.66$ \\
\hline Quercetin & $1.79 \pm 0.046$ & - \\
\hline
\end{tabular}

a) DPPH IC50 ( $\mu$ g plant extracted or $\mu \mathrm{g}$ quercetin/ $\left.1 \mathrm{ml} 10^{-4} \mathrm{M} \mathrm{DPPH}\right), \mathrm{b}$ ) Total phenol (mg eq. gallic acid in $1 \mathrm{~g}$ dried plant). The value results are expressed as the means of three different replicates $\pm \mathrm{SE}$

\section{ETHICS APPROVAL AND CONSENT TO PARTICIPATE}

Not applicable. 


\section{CONSENT FOR PUBLICATION}

Not applicable.

\section{HUMAN AND ANIMAL RIGHTS}

No Animals/Humans were used for studies that are base of this research.

\section{CONFLICT OF INTEREST}

The authors declare no conflict of interest, financial or otherwise.

\section{ACKNOWLEDGEMENTS}

The authors are thankful to the vice chancellor of the research of Shiraz University of the Medical Sciences, Shiraz, Iran for the support of the project (grant number 5663) and Professor Dr. Mohamad Khosravi at the Department of Botany, Shiraz University for identification of the plant material

\section{REFERENCES}

[1] Downie SR, Katz-Downie DS, Spalik K. A phylogeny of Apiaceae tribe Scandiceae: evidence from nuclear ribosomal DNA internal transcribed spacer sequences. Am J Bot 2000; 87(1): 76-95. [http://dx.doi.org/10.2307/2656687] [PMID: 10636832]

[2] Downie SR, Katz-Downie DS, Watson MF. A phylogeny of the flowering plant family Apiaceae based on chloroplast DNA rpl16 and rpoC1 intron sequences: towards a suprageneric classification of subfamily Apioideae. Am J Bot 2000; 87(2): 273-92. [http://dx.doi.org/10.2307/2656915] [PMID: 10675315]

[3] Hedge C, Lamond JM, Rechinge KH, et al. Tamamschian, Umbelliferae.Flora Iranica. Verlagsanstalt Graz, Austria: Akademische Druck- u 1987; Vol. 162.

[4] Singh V, Jain DK. Taxonomy of angiosperms. India: Rastogi Publications 2007.

[5] Rechinger KH. Flora Iranica Verlagsanstalt. Graz: Akademische Druck-u 1972.

[6] Boiss E. Flora Orientalis. 1872.

[7] Navaei MN, Mirza MA. Chemical composition of the essential oils from fruits and leaves of Scaligeria assyriaca Freyn \& Bornm. Tahqiqat-i Giyahan-i Daruyi va Muattar-i Iran 2009; 25(3): 398-402.

[8] Tabanca N, Demirci B, Baser KH, et al. Characterization of volatile constituents of Scaligeria tripartita and studies on the antifungal activity against phytopathogenic fungi. J Chromatogr B Analyt Technol Biomed Life Sci 2007; 850(1-2): 221-9. [http://dx.doi.org/10.1016/j.jchromb.2006.11.041] [PMID: 17169621]

[9] Baser KH, Özek T, Kürkçüoglu M, Güner A. Composition of the Essential Oil from Fruits of Scaligeria lazica Boiss. J Essent Oil Res 1995; 7(5): 557-8.

[http://dx.doi.org/10.1080/10412905.1995.9698586]

[10] Baser KH, Özek T, Kürkçüoglu MK, Güner A. The essential oil of scaligeria lazica boiss. J Essent Oil Res 1993; 5(4): 463-4. [http://dx.doi.org/10.1080/10412905.1993.9698261]

[11] Masoudi S, Ameri N, Rustaiyan A, Moradalizadeh M, Azar PA. Volatile constituents of three Umbelliferae herbs: Azilia eryngioedes (Pau) Hedge et Lamond, Laser trilobum (L.) Borkh. and Falcaria falcarioides (Bornm. et Wolff) growing wild in Iran. J Essent Oil Res 2005; 17(1): 98-100.

[http://dx.doi.org/10.1080/10412905.2005.9698843]

[12] Firuzi O, Miri R, Asadollahi M, Eslami S, Jassbi AR. Cytotoxic, antioxidant and antimicrobial activities and phenolic contents of eleven salvia species from iran. Iran J Pharm Res 2013; 12(4): 801-10. [PMID: 24523760]

[13] Jassbi AR, Mohabati M, Eslami S, Sohrabipour J, Miri R. Biological activity and chemical constituents of red and brown algae from the persian gulf. Iran J Pharm Res 2013; 12(3): 339-48. [PMID: 24250640]

[14] Blois MS. Antioxidant determinations by the use of a stable free radical. Nature 1958; 181(4617): 1199-200. [http://dx.doi.org/10.1038/1811199a0]

[15] Jassbi AR, Singh P, Krishna V, Gupta PK, Tahara S. Antioxidant study and assignments of NMR spectral data for 3', 4', 7trihydroxyflavanone 3', 7-di-O- $\beta$-D-glucopyranoside (butrin) and its hydrolyzed product. Chem Nat Compd 2004; 40(3): $250-3$. [http://dx.doi.org/10.1023/B:CONC.0000039134.46227.1f]

[16] Waterhouse AL. Determination of total phenolics. Current protocols in food analytical chemistry 2002.

[17] Van Den Dool H, Kratz PD. Chromatography 1963; 11: 463-71.

[http://dx.doi.org/10.1016/S0021-9673(01)80947-X] 
[18] Adams RP. Identification of essential oil components by gas chromatography/quadrupole mass spectroscopy. Carol Stream, USA: Allured Publishing Corporation 2001.

[19] Chen CY. Biosynthesis of di-(2-ethylhexyl) phthalate (DEHP) and di-n-butyl phthalate (DBP) from red alga--Bangia atropurpurea. Water Res 2004; 38(4): 1014-8.

[http://dx.doi.org/10.1016/j.watres.2003.11.029] [PMID: 14769421]

[20] Mathur SP. Phthalate esters in the environment:pollutants or natural products? J Environ Qual 1974; 3(3): $189-97$. [http://dx.doi.org/10.2134/jeq1974.00472425000300030001x]

[21] Tian C, Ni J, Chang F, et al. Bio-Source of di-n-butyl phthalate production by filamentous fungi. Sci Rep 2016 ; 6: 19791. [http://dx.doi.org/10.1038/srep19791] [PMID: 26857605]

[22] Rustaiyan A, Nasir Ahmadi A, Jassbi AR, et al. Identification and Determination of Dioctylphthalate in Nepeta laxiflora. J Sci Islamic Azad University 1992; 2: 543-9.

[23] Giust JA, Seipelt CT, Anderson BK, Deis DA, Hinders JD. Determination of bis (2-ethylhexyl) phthalate in cow's milk and infant formula by high-performance liquid chromatography. J Agric Food Chem 1990; 38(2): 415-8. [http://dx.doi.org/10.1021/jf00092a016]

[24] Bullard RW, Holguin G. Volatile components of unprocessed rice (Oryza sativa L.). J Agric Food Chem 1976; 25(1): 99-103. [http://dx.doi.org/10.1021/jf60209a050] [PMID: 1002944]

[25] Yavari A, Shahgolzari SM. Essential oil variation in the populations of Stachys inflata Benth from Iran. Am Eurasian J Agric Environ Sci 2013; 13: 461-4.

[26] Srinivasan GV, Sharanappa P, Leela NK, Sadashiva CT, Vijayan KK. Chemical composition and antimicrobial activity of the essential oil of Leea indica (Burm. f.) Merr. flowers.

[27] Fromme H, Küchler T, Otto T, et al. Occurrence of phthalates and bisphenol A and F in the environment. Water Res 2002; 36(6): 1429-38. [http://dx.doi.org/10.1016/S0043-1354(01)00367-0] [PMID: 11996333]

\section{(C) 2017 Jassbi et al.}

This is an open access article distributed under the terms of the Creative Commons Attribution 4.0 International Public License (CC-BY 4.0), a copy of which is available at: https://creativecommons.org/licenses/by/4.0/legalcode. This license permits unrestricted use, distribution, and reproduction in any medium, provided the original author and source are credited. 